\title{
Laboratory Findings; Remembering Hakan Rydhström; Twins' Extraordinary Lives
}

\author{
Nancy L. Segal \\ Department of Psychology, California State University, United States of America
}

\section{Laboratory Findings: Not Twins, Twins, Not Twins}

Comparative examination of DNA markers is the most accurate scientific procedure for diagnosing the zygosity of same-sex twin pairs (see Segal, 2000). Co-twin concordance for 13 short tandem repeat (STR) DNA markers indicates monozygotic (MZ) twins with greater than $99 \%$ probability. Conversely, discordance for any marker indicates dizygotic (DZ) twins with complete certainty. Virtually noone would question these results when provided by a genetics laboratory; but two mothers did, as well as me, in an intriguing case involving infant girls adopted from China. (Note: In what follows the names, locations and other identifying information of the families have been changed in the interest of confidentiality.)

In August 2005 I received an email message from Susan Kay, who recently adopted a female baby from China: 'We have just returned from China (in June) with our second little girl from there and are now exploring the possibility that she has a twin that was actually in the same group with us! We haven't begun the testing process ... We're just beginning to explore all of this and, of course, will do more if it's confirmed that the girls are related'.

The large number of Chinese girls available for international adoption is well known - approximately 4500 Chinese children (mostly females) were adopted in the United States in 2001 ('A Chinese Hotel,' 2003). Their
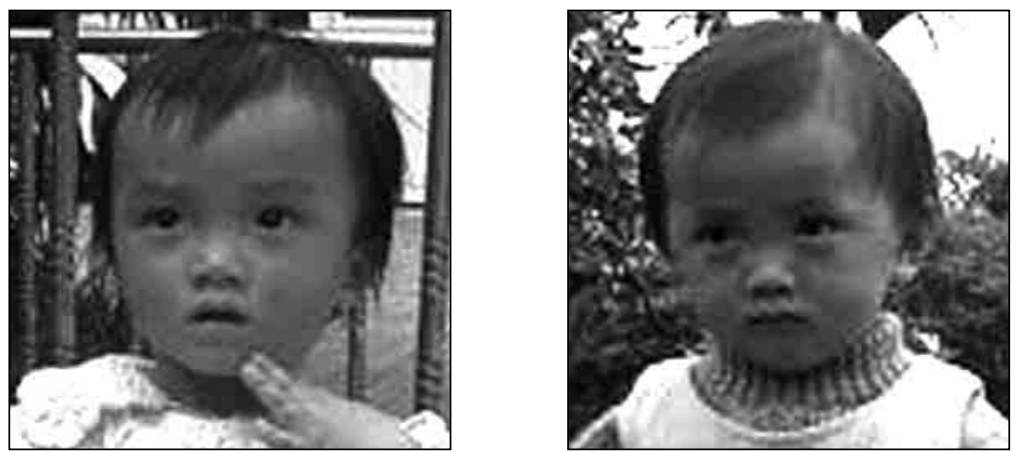

availability is largely due to China's One-Child Policy, enacted in 1979 or 1980 , to restrict population growth. The policy ended up substantially increasing the birth proportion of male children, who are favored in that culture - this came about due to forced abortions of female fetuses, heavy fines for delivering female infants and frequent abandonment of baby girls.

Less well known is the fact that female infants left on orphanage steps, church entrances and market squares included a number of twin girls, some of whom were adopted separately. The number of such pairs is uncertain so it is impossible to know the proportion of pairs that have been reunited. The extraordinary lives of one lucky set, Lily and Gillian, were the subject of an essay, 'A Good-News Story', in my recent book, Indivisible by Two: Lives of Extraordinary Twins (Segal, 2005a; also see Wray, 2005). They were also featured on a segment of ABC's Good
Morning America, on August 17, 2005. A web site established by parents who adopted one fraternal female twin (http://groups.yahoo.com/group/ sisterfar) assists families searching for their child's twin or sibling.

I e-mailed Susan to arrange a telephone interview in order to learn more about her case. I also obtained contact details for the second mother, Karen Lewis, who had adopted the other putative twin. Information was graciously provided by both women, allowing me to piece together the following series of events.

In June 2005, Susan and Karen, both 48 years of age, and their husbands were two of 14 couples traveling to Beijing, China, to adopt daughters. Susan had seen a television

Address for correspondence: Nancy L. Segal, Department of Psychology, California State University, Fullerton, CA 92834, USA.

E-mail: nsegal@fullerton.edu 
program on the plight of the abandoned Chinese girls and believed that God wanted her to adopt one of these children. In fact, several years earlier she had traveled to China to adopt her older daughter, age 4 , but was eager to do this all again. She would name her new daughter Sarah. Susan already had two grown biological sons. Karen had worked in Hong Kong in the mid-1990s and was acutely aware of the horrific consequences of China's population policy. This awareness prompted her to adopt one of the abandoned Chinese girls, whom she named Kathy. Karen already had one biological daughter, age 5 .

Karen was the 13 th parent to receive her child. While she waited, she recalls seeing Susan's little girl and thought how strongly this child resembled her prospective daughter, shown in a photograph she had received earlier. Karen actually approached Susan and watched her holding the little girl in her arms. However, in China the two women spent little time together and little time thinking about the possibility that their girls could be twins. As Karen said, 'When you go there you only have eyes for your own child and you are falling in love with her'. But other people in the group had noticed the resemblance between the two children who were then 16 months of age.

When Susan arrived home and resumed contact with some of her traveling companions, they strongly suggested to her that the two girls could be related. She then contacted adoption agency officials who assured her that if the girls had been found in different locations - which they had - then they could not be twins. (Sarah was found at a middle school and Kathy was found on the orphanage steps.) But this response could not be trusted; the adoption facilitator who had managed Lily and Gillian's case had made the same claim. Susan also called Karen who lived approximately 2000 miles away.

As indicated, Karen was aware of the girls' resemblance, and the two mothers began trading bits of information. As the babies were abandoned, their birthdays could only be estimated based upon their physical development and the time they were found. The estimated interval between them was only 10 days - November 10 and November 17 - so a twin relationship was plausible. Both mothers also noticed that their girls looked different from most other Chinese children, but similar to one another - they had brown hair, round flat faces, somewhat rounded eyes and tiny chins. They were also relatively small in body size ('waiflike'), even though they were the two eldest children of the group. (At age 16 months Sarah and Kathy each weighed 18 pounds, while most children 17 months and younger weighed 28 pounds.) Both girls also had a flat bridge on their nose. Their mothers also described them as very active children who loved to climb, dance and listen to music. Both were also picky eaters. The possibility that their daughters were twins was further strengthened by the fact that their older daughters, sons and husbands could not tell the girls apart in the pictures.

Susan forwarded five pairs of photos to me in which she had placed Sarah on one side and Kathy on the other side. When I opened the e-mail attachment I did not know this, and when the first set appeared on the screen I thought I was seeing two photographs of the same child. Once I realized that the pictures were of different children, I was certain that they were identical twins. I arranged to obtain buccal smears from both girls to confirm this in a laboratory setting.

Laboratory results arrived in my office about 2 weeks later and they were not what anyone had expected: The infant girls, Sarah and Kathy, were discordant for all 10 tested markers, ruling out the possibility that they were identical twins. These results also made it very unlikely that they were fraternal twins - a laboratory staff member explained that at least two markers should match in the case of DZ twins. Of course, DZ twins can be completely discordant for all measured characteristics, but information on the biological parents would then be required to confirm that the girls were related, and this was unavailable. The likelihood was that Sarah and Kathy were not related at all.

When I telephoned Susan to tell her she was 'shocked' and 'disappointed'. It seemed impossible that the girls should match across a number of unusual physical features and not be related. She e-mailed me later saying, 'This is just such a weird feeling for me because I really, really expected that they were twins and my reaction has caught me quite by surprise. I can't believe I'm this upset over it'.

Karen was also very 'surprised' when I called her with the results. Was she disappointed? 'Yes and no it would have been nice if the girls had a biological link, but it is what it is'. She admitted that this news made things easier for the families who lived so far apart. An additional concern was that Karen's older daughter was feeling some unsettling effects of her sister's possible twinship. The little girl wondered, 'Who is more of a sister to Kathy-her twin or me?' Still, twinship is unique and there was disappointment on the part of both families, evident in an e-mail message I received from Susan later that day.

Susan wrote, 'I am still trying to digest some of this information from the test results. I e-mailed one of the other moms that has Chinese twins ... needless to say, she's shocked with the result too'. The other mother had asked, 'Did they use a "siblingship index?" Obviously the girls are not identical twins. That's fine. But did they use the markers to compute a likelihood of sibship, which resulted in not related?' Repeated testing using an increased number of markers could produce some matches, perhaps meaningful or perhaps by chance. However, both families were correctly committed to doing everything possible to determine the truth about their daughters, given their sensitivity to the importance of the twin relationship. Understandably, probabilities rather than certainties were frustrating for them.

Susan and I spoke again later than afternoon and we agreed that I should contact the laboratory to request that the test be repeated - perhaps a human error had been made. ('Well, maybe something different will show 
with the other test ... Fingers crossed'.) It was then that I learned that not one, but two samples with Kathy's name had been sent to the laboratory. Twin-testing kits typically include two packets (one for each twin), presuming that they live together. Karen, in her eagerness to obtain her daughter's sample accurately, had repeated the process. When the laboratory received them, they had chosen one at random to compare with Sarah's - so perhaps the chosen sample had been contaminated. The staff agreed to perform the test again, labeling the three samples 'A', 'B' and 'C', and running them blindly. They also agreed to complete the tests quickly.

Meanwhile, I received a message from one of Susan's friends, a woman who had also adopted a Chinese daughter. Earlier, she had suspected that her child was a reared-apart twin, based on her behavioral and physical resemblance to another child. DNA tests indicated a $72 \%$ probability of full sibship and $90 \%$ probability of half-sibship. 'As soon as they met, we realized that they were much more alike in person than in photos ... They had an instant bond. It was hard to explain how two [4-and-a-halfyear-old] children who just met were so crazy about each other. They rarely left each other's side'.

At about this time I was in Washington, DC, filming a program on twins for Discovery Health along with Dr Kerry Jang (this program is scheduled to air on March 12, 2006). I called my answering machine to find an excited message from one of the laboratory staff. It seemed that samples 'A' and 'B' matched on all 10 markers, making the girls identical twins. Sample 'C' (Kathy's duplicate sample) showed a genotype that differed from the other two; perhaps Karen or someone else had inadvertently touched it prior to mailing.

I called Susan and Karen as soon as I returned to California. Susan was 'ecstatic', calling the news 'a miracle - it is bigger than us' and Karen said she felt 'goosebumps'. But Karen was cautious and wanted to have another test conducted by a different laboratory. This was not an unreasonable reaction; after all, two tests had been completed thus far with conflicting results. The issue in question was too important to be taken lightly — acknowledging false twins could be just as unfortunate as overlooking real ones.

Karen and Susan forwarded new DNA samples to a different laboratory and we waited. A few weeks later we had an answer: the girls were not twins and were probably not related. Two tests out of three should have satisfied everyone, but two nagging facts remained: (1) the girls looked so much alike in unusual ways, and (2) the second test had confirmed identical twinning. There was also a new wrinkle: could we really trust the latest test? Once a laboratory analysis is suspected of error it colors reactions to subsequent tests. What if the third test had also been contaminated?

In an attempt to resolve lingering doubts over Sarah and Kathy's twinship, I contacted the original laboratory. They generously agreed to repeat comparison of DNA markers for buccal smear samples 'A', 'B' and ' $\mathrm{C}$ ', to perform a zygosity test using blood drawn by medical technicians (to avoid any possibility that one, or both, of the mothers had handled the swab incorrectly), and to analyze a buccal smear provided by Karen (who had originally submitted two samples for her daughter); this would be done to settle the identity of sample ' $C$ ' (Kathy's first sample, the one that did not match Sarah's) and to perform a sibship test.

About 2 weeks later it was determined that the girls were not identical twins. A review of quality control measures revealed where the mistake had occurred: one of the cards labeled 'Kathy' had been inadvertently switched with the card marked 'Sarah', thus explaining the erroneous result of $\mathrm{MZ}$ twins. It was also determined that Karen's genotype differed from the one that differed from Sarah's in the first test - so the identity of that first genotype remains a mystery. Finally, the sibship index was .00005588 , indicating a probability of full sibship of only .0056\%. According to the report, a sibship index of $80 \%$ or greater is considered to be significant.
I talked with both mothers once these results were known. Karen accepted the findings - three out of four tests showing lack of a biological relationship had convinced her. She also admitted to being somewhat skeptical of the report indicating identical twins. 'The girls looked similar, but not identical. But I was told by a geneticist that identical twins do not always look exactly the same. So we had to do the tests - we had to know why one came out one way and another came out another way, just to be sure. Now there will be no more tests'. She continued, 'Sure, I felt special at the idea of having a twin daughter. I would have wanted a relationship for them. Twinship is important, it has a special affinity'. Karen plans to stay in touch with Susan, probably over the Internet, to see how the girls progress, but it is unlikely that they will meet.

Susan said, 'The first time I heard the news that they were unrelated I said "no way" - I expected the tests to confirm what we all suspected [identical twins]. There is so much about the girls that is unknown, no biological link. The possibility that they were identical twins was like a gift - although it would have meant incorporating a new relationship into our family. It also would have meant explaining things to my older daughter - what if she had wanted to know where her twin was? But when the laboratory said that they were identical twins it felt like it fit'.

The most difficult issue is that sibling relationships are described as probabilities. 'What is the truth?' Susan asked. 'We knew what was in our hearts, but we needed science to back it up'. When she sees Sarah make a certain expression or gesture she 'flashes back' to China and to memories of Kathy doing the same thing. She brought up the tiny probability that the girls could be related, emphasizing that as a parent she needed to explore every avenue. Susan still wonders how many DNA markers would need to be compared to know if the girls were sisters. Or perhaps cousins ... 


\section{Remembering Hakan Rydhström}

Many ISTS members knew our esteemed associate editor and colleague, Dr Hakan Rydhström, in the Department of Obstetrics and Gynecology at University Hospital, Lund, Sweden. I did. I met Hakan in September 1988, at the 6th Working Party on Multiple Pregnancy, at Northwestern University in Chicago. I sat next to him at lunch and was fascinated to hear about his studies of physiological correlates and care-taking practices related to multiple pregnancies. I was curious to learn why he had become involved with twins and their families. He answered me with a characteristic smile and twinkle in his eye. 'I do it because I am fond of women', he said. He was clearly captivated by the women's pregnancy experiences - and twin births pose greater challenges for families and physicians than nontwin births, both physically and emotionally. Hakan was dedicated to making their experiences as pleasant and as stress-free as possible.

Hakan delivered his research paper on the second day of the meeting. It was entitled 'Birthweight Discordance $\geq 1.0 \mathrm{~kg}$ in Twin Pregnancy, No Effect of Abdominal Delivery on Perinatal Mortality, or on Early Neonatal Morbidity'. He presented findings on 267 twin pairs born between 1973 and 1983, identified via the Swedish Twin Registry:

No association was found between perinatal mortality figures and a sevenfold increase in cesarean section rates. No significant differences in perinatal mortality, or Apgar score less than 7 at 5 minutes, was found when vaginal and abdominal delivery were compared for all twins, for all second twins, or for all second twins in breech presentation. No difference was found between small twins born vaginally, but the smaller twin had a significantly higher perinatal mortality than its larger fellow twin. The results of this study seem to indicate that for twin pairs discordant in birthweight greater than of equal to $1.0 \mathrm{~kg}$, abdominal delivery did not improve perinatal prognosis.

Hakan Rydhström was tragically killed in a boating accident in Sweden in April 2005. He leaves us with many warm memories of friendship and scholarship. The sentiments of his colleagues are beautifully summarized in comments from Ulla-Britt Wennerholm, reprinted below. They are from an October 29, 2005 e-mail message to Dr Elizabeth Bryan:

\begin{abstract}
Dear Elizabeth!
I am just home again after the annual perinatal meeting this week in Stockholm, where you visited us some years ago! I was just thinking of you and also we of course talked about Håkan at that meeting, he was such a central person at this meeting, we are many that miss him very much!

Ulla-Britt
\end{abstract}

Hakan's photograph was graciously provided by Marion Paterson, Administrator of the Multiple Births Foundation, in London. A list of his publications follows.

\section{Dr Hakan Rydhström Publications*}

Saleem, Z., \& Rydhstrom, H. (2004). Vaginal hematoma during parturition: A population-based study. Acta Obstetricia et Gynecologica Scandinavica, 83, 560-562.

Ohlsson, G., Buchhave, P., Leandersson, U., Nordstrom, L., Rydhstrom, H., \& Sjolin, I. (2001). Warm tub bathing during labor: Maternal and neonatal effects. Acta Obstetricia et Gynecologica Scandinavica, 80, 311-314.

Arnlind, M. H., Brege, K. G., AbergWistedt, A., Bejhed, L., Gardmark, S., Kron, B., Lindberg, M., Rydhstrom, H., Rynnel-Dagoo, B., Stymne, B., \& Thorburn, W. (2001). Patient-based care registries as a tool to follow-up services. Lakartidningen, 98, 25-29. [Swedish]

Ryding, E. L., Wijma, B., Wijma, K., \& Rydhstrom, H. (1998). Fear of childbirth during pregnancy may increase the risk of emergency cesarean section. Acta Obstetricia et Gynecologica Scandinavica, 77, 542-547.

Rydhstrom, H. (1998). More than one: When only one twin survives. Jordemodern, 111, 17-18. [Swedish]

Cordesius, I., \& Rydhstrom, H. (1998). More than one: Birth of 2 twins. Jordemodern, 111, 15-16. [Swedish]

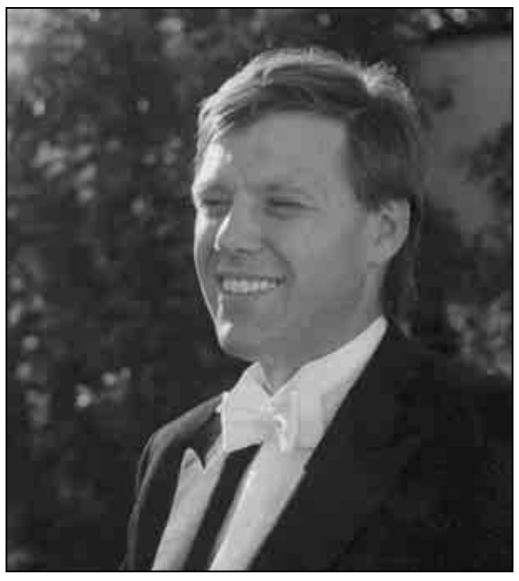

Wolner-Hanssen, P., \& Rydhstrom, H. (1998). Ovum resetting after in vitro fertilization: More cost-efficient with one egg than with two. Lakartidningen, 95, 292-298. Review. [Swedish]

Aberg, A., Rydhstrom, H., Kallen, B., \& Kallen, K. (1997). Impaired glucose tolerance during pregnancy is associated with increased fetal mortality in preceding sibs. Acta Obstetricia et Gynecologica Scandinavica, 76, 212-217.

Rydhstrom, H., Tyden, T., Herbst, A., Ljungblad, U., \& Walles, B. (1994). No relation between maternal weight gain and stillbirth. Acta Obstetricia et Gynecologica Scandinavica, 73, 779-781.

Walles, B., Tyden, T., Herbst, A., Ljungblad, U., \& Rydhstrom, H. (1994). Maternal health care program and markers for late fetal death. Acta Obstetricia et Gynecologica Scandinavica, 73, 773-778.

Rydhstrom, H. (1994). Discordant birthweight and late fetal death in like-sexed and unlike-sexed twin pairs: A population-based study. British Journal of Obstetrics and Gynaecology, 101, 765-769.

Lindberg, B., Kjellmer, I., Wennergren, M., \& Rydhstrom, H. (1994). Multiple pregnancy: An increasing obstetric and pediatric problem. Lakartidningen, 91, 806, 809-11. [Swedish]

Andolf, E., Iosif, C. S., Jorgensen, C., \& Rydhstrom, H. (1994). Insidious urinary retention after vaginal delivery: Prevalence and symptoms at follow-up in a population-based study. Gynecologic and Obstetric Investigation, 38, 51-53.

Rydhstrom, H., \& Ingemarsson, I. (1993). Prognosis and long-term follow-up of a twin after antenatal death of the cotwin. The Journal of Reproductive Medicine, 38, 142-146.

Rydhstrom, H. (1992). A birthweight-forgestation standard based on 4737 twins born in Sweden between 1983 and 1985. Acta Obstetricia et Gynecologica Scandinavica, 71, 506-511. 
Rydhstrom, H. (1992) Gestational duration and birth weight for twins related to fetal sex. Gynecologic and Obstetric Investigation, 33, 90-93.

Rydhstrom, H., \& Ingemarsson, I. (1991). A case-control study of the effects of birth by caesarean section on intrapartum and neonatal mortality among twins weighing 1500-2499 g. British Journal of Obstetrics and Gynaecology, 98, 249-253.

Rydhstrom, H., \& Ingemarsson, I. (1991). No benefit from conservative management in nulliparous women with premature rupture of the membranes (PROM) at term. A randomized study. Acta Obstetricia et Gynecologica Scandinavica, 70, 543-547.

Rydhstrom, H. (1991). Twin pregnancies and mode of delivery-too many cesarean sections? Journal of Perinatal Medicine, 19(Suppl. 1), 220-228.

Rydhstrom, H., Walles, B., \& Owman, C. (1990). Effects of oophorectomy, sympathetic denervation and sex steroids on uterine norepinephrine content and myometrial contractile response to norepinephrine in the guinea pig. Neuroendocrinology, 52, 332-336.

Rydhstrom, H. (1990). Prognosis for twins with birth weight less than $1500 \mathrm{gm}$ : The impact of cesarean section in relation to fetal presentation. American Journal of Obstetrics and Gynecology, 163, 528-533.

Rydhstrom, H., Ingemarsson, I., \& Ohrlander, S. (1990). Lack of correlation between a high caesarean section rate and improved prognosis for lowbirthweight twins (less than $2500 \mathrm{~g}$ ). British Journal of Obstetrics and Gynaecology, 97, 229-233.

Rydhstrom, H., \& Cullberg, G. (1990). Pregnancies with growth-retarded twins in breech-vertex presentation at increased risk for entanglement during delivery. Journal of Perinatal Medicine, $18,45-50$.

Rydhstrom, H. (1990). Prognosis for twins discordant in birth weight of $1.0 \mathrm{~kg}$ or more: The impact of cesarean section. Journal of Perinatal Medicine, 18, 31-37.

Rydhstrom, H., \& Ingemarsson, I. (1990). Interval between birth of the first and the second twin and its impact on second twin perinatal mortality. Journal of Perinatal Medicine, 18, 449-453.

Rydhstrom, H. (1990). The effects of maternal age, parity, and sex of the twins on twin perinatal mortality: A populationbased study. Acta Geneticae Medicae et Gemellologiae, 39, 401-408.

Rydhstrom, H., Walles, B., \& Owman, C. (1989). Myometrial norepinephrine in human pregnancy: Elevated levels in various disorders leading to cesarean section. The Journal of Reproductive Medicine, 34, 901-904.

Rydhstrom, H., \& Ingemarsson, I. (1989). The extremely large fetus: Antenatal identification, risks, and proposed management. Acta Obstetricia et Gynecologica Scandinavica, 68, 59-63.

Olofsson, P., Rydhstrom, H., \& Sjoberg, N. O. (1988). How Swedish obstetricians manage premature rupture of the membranes in preterm gestations. American Journal of Obstetrics and Gynecology, 159, 1028-1034.

Iosif, C. S., Bekassy, Z., \& Rydhstrom, H. (1988). Prevalence of urinary incontinence in middle-aged women. International Journal of Gynaecology and Obstetrics, 26, 255-259.

Rydhstrom, H., \& Iosif, C. S. (1988). Urodynamic studies before and after retropubic colpo-urethrocystopexy in fertile women with stress urinary incontinence. Archives of Gynecology and
Obstetrics, 241, 201-207.

Rydhstrom, H. (1988). Twin pregnancy and the effects of prophylactic leave of absence on pregnancy duration and birth weight. Acta Obstetricia et Gynecologica Scandinavica, 67, 81-84.

Batra, S., Owman, C., Rydhstrom, H., \& Sjoberg, N. O. (1987). Modulation by continuous oestrogen treatment and by progesterone of oestrogen receptors in the rabbit uterus. The Journal of Endocrinology, 115, 199-203.

Rydhstrom, H., Nordenskold, F., Grennert, L., Ohrlander, S., \& Aberg, A. (1987). Routine hospital care does not improve prognosis in twin gestation. Acta Obstetricia et Gynecologica Scandinavica, 66, 361-364.

Olofsson, P., \& Rydhstrom, H. (1985). Twin delivery: How should the second twin be delivered? American Journal of Obstetrics and Gynecology, 153, 479-481.

Olofsson, P., \& Rydhstrom, H. (1985). Management in second stage of labour in term twin delivery. Acta Geneticae Medicae et Gemellologiae, 34, 213-216.

Rydhstrom, H., \& Ohrlander, S. (1984). Twin pregnancies in Helsingborg 1971-1980. Changes in the diagnosis and treatment. Lakartidningen, 81, 346-349. [Swedish]

Bagger, P., \& Rydhstrom, H. (1981). Acute appendicitis during pregnancy. Jordemodern, 94, 83-89. [Swedish]

Bagger, P., \& Rydhstrom, H. (1980). Acute appendicitis during pregnancy. Lakartidningen, 77, 4570-4572.

${ }^{*}$ References given here were drawn only from MEDLINE so the list may not be complete.

\section{Twins' Extraordinary Lives}

\section{Conjoined Twins I}

Identical twins, Ahmed and Mohamed Ibrahim, from Egypt, were conjoined twins, connected at the tops of their heads ('Texas: 2 Happy Boys', 2005). They came to the United States over 3 years ago for surgical separation in Texas. Their 34-hour operation took place on October 2, 2005, after which the twins remained under close medical supervision. They are finally returning home, separated and wearing specially constructed helmets to protect their skulls. A photograph accompanying one of the newspaper articles shows one twin boy leaning over to kiss his smiling brother.

This story will, no doubt, comfort other families with conjoined twins, as well as inspire physicians and surgeons working with such difficult cases. Of course, decisions regarding the management and care of conjoined twins should be made confidentially by families and physicians, on a case-by-case basis.

\section{Conjoined Twins II}

I was in Chicago, Illinois, the night of December 19, 2005, as a guest on
WGN radio, hosted by Milt Rosenberg. Milt, now Professor Emeritus, was a faculty member in my department at the University of Chicago while I was completing my doctoral degree, but we did not know each other then. Toward the beginning of the 2-hour program he asked me if I had ever studied twinship in ancient Egypt and I replied that I had not. If only he had asked me that question a day later...

I left Chicago the following morning, en route to New York. Once airborne, I turned to the New York Times' 
Science section. The front page headline, 'A Mystery, Locked in a Timeless Embrace' (Wilford, 2005) and subject matter would have caught the attention of any ISTS member. In 1964, researchers discovered the matched images of two male figures on a tomb outside Cairo. The dates during which these men lived are estimated to be 2380 to 2320 BC. Now, several new and controversial theories of who and what these figures represent have been put forth by archeologists from around the world. One explanation is that the two men, Niankhkhnum and Khnumhotep, were conjoined twins. The evidence, while fascinating, is also circumstantial: the similar physique, the close embrace and the resemblance (in pose) to Chang and Eng. However, the researchers acknowledged that no obvious physical connection can be detected; see Segal (2005b) for commentary.

Should the conjoined twin theory be confirmed, these images would then become the earliest pictorial representation of human twins. Currently, the first recorded birth of conjoined male twins is believed to have occurred in the 10th century Byzantium (Pentogalos \& Lascaratos, 1984).

\section{Twin Videos}

I received a video and DVD catalogue from a colleague with the note, 'You and your research area have finally arrived. For the first time ever I see that there is an actual listing for "twins"'. Turning to page 14, I found descriptions of four twin-based videos: 'Mystery of Twins', 'The Mystery of Twins', 'Twin Connection' and 'Body Doubles: The Twin Experience'. It was gratifying to see this, given that twin research has endured (and survived) its share of challenges and criticisms (see Segal, 2000). One of the programs,
'Twin Connection', was listed as a bestseller, further evidence of how popular twins and twin studies have become (Insight Media, 2005).

\section{Vaudeville Twins}

A new exhibition, 'Vaudeville Nation' is on display at the New York Public Library for the Performing Arts. Vaudeville was a popular cultural form in the United States from the 1880s to the 1930s. The exhibition includes a vast collection of scripts, newspaper clippings, stage designs and other materials. The picture accompanying the news item would be especially interesting to twin researchers - it is entitled 'The Sensation of Vaudeville' and depicts conjoined twins, Violet and Daisy Hilton (Rothstein, 2005).

The twins are wearing identical blue dresses and hair ribbons, and are holding saxophones. The Hilton sisters were also the subject of a 1997 Broadway musical, Side Show.

\section{John and Greg Rice, an Amazing Pair}

The death of identical twin John Rice, at age 53, was written up in newspapers everywhere (Goodnough, 2005). His death was due to a heart attack.

John and his twin brother Greg, of West Palm Beach, Florida were famous for many things. They were motivational speakers. They were real estate millionaires. They were movie actors. They were also born with dwarfism at 2 feet, 10 inches tall they were probably the world's shortest adult twins. They were abandoned at birth and adopted by a foster family who supported them physically and emotionally. Sadly, their foster parents passed away from cancer during the twins' teenage years. Their situation would have been psychologically debilitating to most people, but John and
Greg lived their lives to the fullest. When John died, flags were flown at half-mast outside the City Hall in Lake Worth, Florida, where the twins lived.

Like most identical twins, Greg commented that he and his twin brother spoke on the telephone many times each day. There was, however, one topic they had never discussed the death of one of them.

\section{References}

A Chinese hotel full of proud American parents. (2003, March 31). New York Times, p. A40.

Goodnough, A. (2005, November 14). A community mourns a favorite son who defied the odds and convention. New York Times, p. A14.

Insight Media. (2005). Twins. Psychology on video and DVD. New York: Insight Media.

Pentogalos, G. E., \& Lascaratos, J. G. (1984). A surgical operation performed on Siamese twins during the tenth century in Byzantium. Bulletin on the History of Medicine, 58, 99-102.

Rothstein, E. (2005, November 19). At the edge of respectability, a celebration. New York Times, pp. B17, 13.

Segal, N. L. (2000). Entwined lives: Twins and what they tell us about human behavior. New York: Plume.

Segal, N. L. (2005a). Indivisible by two: Lives of extraordinary twins. Cambridge, MA: Harvard University Press.

Segal, N. L. (2005b, December 27). Letter to the Editor. New York Times (online).

Texas: 2 happy boys, 2 separate heads. (2005, November 19). New York Times, p. A11.

Wilford, J. N. (2005, December 20). A mystery, locked in a timeless embrace. New York Times, pp. F1, F4.

Wray, N. R. (2005). Review: Indivisible by two: Lives of extraordinary twins. Twin Research and Human Genetics, 8, 666-668. 